\title{
Nasiba Yusupova, Türkçe - Özbekçe Sözlük, Türk Dil Kurumu Yayınları, ISBN 978-975-16-3486-9, Ankara 2018, 674 s.
}

\author{
Saidbek BOLTABAYEV*
}

Sözlük bilimi (leksikografi) kelimeleri kodlama, kelimelerin listesini oluşturma, sözlük yapma bilimi ve sanatıdır. Dolaysıyla bu bilim alanında hazırlanan eserler yazıldığı dilin hazineleri olup, bu dilin söz varlığını geleceğe taşıma noktasında çok önemli bir araçtır.

Sözlükleri zaman bakımından ikiye ayırmak mümkün: tarihî ve modern sözlükler. Tarihî sözlükler kelimelerin listesi ve başka dil veya dillerdeki karşılığ1nın yanı sıra gramer kurallarını, bazen telaffuz şekillerini içerir. Tarihî sözlüklerin bir türü olan manzum sözlükler, sözlük biliminin sanat olarak tanımlanmasına sebep olmuştur.

İslam öncesine ait dönemlerde yazılan bazı sözlük parçalarının (Turfan’da bulunan Budizm muhitinde yazılmış Çince - Türkçe sözlük parçaları) günümüzde bilim adamları tarafından tespit edilmiş olması Türklerde sözlük biliminin çok eski zamanlara dayandığını göstermektedir. (Kasımcan Sadıkov Tarixiy Leksikografiya; 2011: 6) Türklerin İslamiyeti kabul etmesinden sonra Arapların Türkçe anlaması ve öğrenmesi için Kaşgarlı Mahmud tarafından kaleme alınan Divanü Lügati’t-Türk Türkçe sözlükler arasında bilim dünyasınca bilinen geniş kapsamlı ilk sözlüktür. XVI. yüzyılda yazılan Abuşka lügati iki Türk lehçesi üzerinde yazılan ilk sözlük mahiyetindedir. Çağatayca - Osmanlıca olarak hazırlanan Abuşka lügati Çağatayca eserlerin, özellikle Nevaî eserlerinin Osmanlıcada anlaşılması

* Dr. Öğr. Üyesi, Karabük Üniversitesi Çağdaş Türk Lehçeleri ve Edebiyatları Bölümü, Türkiye. 
için kaleme alınmıştır. Bu sözlük mesafe olarak birbirinden uzakta kalan Türk halkları arasında köprü görevini görmüş, çeşitli dönemlerde çokça nüshaları istinsah edilmiştir.

Daha sonraki dönemlerde yazılan Şeyh Süleyman Buharî Efendi'nin Lügat-ı Çağatay ve Türkî-i Osmanî, V.V. Radlov'un Opıt Slovarya Tyurkskih Nareçiy (Türk Lehçeleri Sözlüğü Denemesi) (Sankt Peterburg, 1893-1911) adlı çalışmaları karşılaştırmalı sözlük olması bakımından önemlidir.

Azerbaycan, Özbekistan, Kazakistan, Kırgızistan ve Türkmenistan Cumhuriyetlerinin bağımsızlığını elde etmesinin ardından Türkçe sözlük çalışmaları hem bu ülkelerde hem de Türkiye'de hizla ilerledi. 1991 y1lında Türkiye Cumhuriyeti Kültür Bakanlığı tarafindan Karşılaştırmalı Türk Lehçeleri Sözlüğü I-II yayımlandi.

Bağımsızlık sonrasında aynı şekilde Türkçe - Özbekçe, Özbekçe - Türkçe sözlük çalışmalarının yapılması Özbekistan ve Türkiye arasında köprü vazifesini görmesi bakımından önem kazanmıştır. $\mathrm{Bu}$ anlamda ilk çalışmalar arasında Nizomiddin Mahmud ve Ertuğrul Yaman'ın Türkçe - Özbekçe, Özbekçe - Türkçe Sözlük (Taşkent 1993), Berdak Yusuf'un Türkçe - Özbekçe, Özbekçe - Türkçe Sözlük (Taşkent 1993) göstermek mümkündür. 1994 yılında Berdak Yusuf ve Mehmet Mahur Tulum'un hazırladığı Özbekistan Türkçesi - Türkiye Türkçesi, Türkiye Türkçesi - Özbekistan Türkçesi Sözlüğü İstanbul'da yayımlandı. Daha sonra Berdak Yusuf Özbekçe - Türkçe ve Türkçe - Özbekçe İzahlı Sözlük (Taşkent 1997), Türkçe - Özbekçe Sesteş Kelimeler Sözlüğü (Taşkent 2009) eserlerini hazırlayarak bu alanda yapılan çalışmalara hız kazandırdı. Emek Üşenmez, Saidbek Boltabayev, Gülşah Tuğlacı tarafından yayımlanan Özbekçe - Türkçe Sözlük (İstanbul 2016) ise 23 binden fazla madde başı kelime içermektedir. Dolaysıyla alanında ilk kapsamlı çalışma olmuştur.

Ancak günümüze kadar Türkçe - Özbekçe geniş kapsamlı bir sözlük bulunmamaktaydı. Nasiba Yusupova tarafindan hazırlanan Türkçe - Özbekçe Sözlükte 35 bin civarında kelimenin yer alması bu alanda önemli bir boşluğu doldurmaktadır. Sözlüğü Prof. Dr. Nadirhan Khasanov incelemiştir.

Sözlüğün sunuş kısmında aşağıdaki ifadelere yer verilmiştir: 
“Türkçe - Özbekçe Sözlük Türk halkı ve Özbek halkı arasinda kültür köprüsü oluşturmak amacıyla hazırlanmıştır.

Özbeklerin Türkiye Türkçesini öğrenmesi, Türkçe konuşabilmesi, eserler okuyabilmesi, kitap çevirileri yapabilmesi için imkân sağlayacaktır. İki kardeş ülke arasında ekonomik, kültürel ve sosyal iletişimi kolaylaştıracaktır."

Sözlüğün hazırlanmasında madde başları hazırlarken Türk Dil Kurumu tarafından 2012 yılında yayımlanan Yazım Kllavuzu'nun 27. baskısı esas alınmış, eserin başlangıcında "Türk ve Özbek Alfabesi”, "Türkçe Harflerin Telaffuzu” ve "Kısaltmalar" bölümlerine yer verilmiştir.

Madde başı kelimeler siyah koyu harflerle Türk alfabesinin sırasına göre dizilmiş. Kelime türü, kökeni, kullanım sahası parantez içinde italik olarak yazılmıştır. Daha sonra kelimenin Özbekçe karşılığı verilmiştir. Kelimenin farklı anlamları sayılarla ayrılmıştır. Örnek:

ab (is., Far. esk.) Ob, suv.

abanmak (-e) 1. Cho'nqaymoq. 2. Cho'kkalamoq, cho'kka tushmoq. 3. Suyanmoq, yaslanmoq, yastanmoq.

açlık, - $\breve{\text { ğ }}$ (is.) Ochlik.

ada (is., cŏg.) Orol (jug'.).

boyun, -ynu (1. is., anat., 2. is., coğ., 3. is., 4. is.) 1. Bo'yin (anat.). 2. Bo'yin (jug'.). 3. Bo'yin, bo' $\mathrm{g}^{\prime} \mathrm{iz}$ (ba'zi asboblarning ingichka uzunchoq qismi). 4. Gardan, zimma, ust.

mutlaka ( $z f . A r$.) Mutlaqo, tamomila, batamom.

Bütün yukarıda belirtilenlerin yanı sıra Türkçe - Özbekçe Sözlükte bazı teknik hatalar bulunmaktadır. Sözlükte madde başı kelimeleri genel olarak koyu harflerle yazılırken bazı durumlarda hem kalın hem italik olmuştur:

şafak, - $\breve{g} \boldsymbol{l}$ (is., Ar.) Shafaq.

şafak pembesi (is., sf.) Shafaqrang.

Kitabın 12. sayfasında Özbek alfabesine yer verilmiştir. Tabloda Özbek alfabesinde bulunan büyük i harfi, I olarak doğru gösterilmişse de sözlük kısmında İ şeklinde gösterilmiştir: 
içmek (-i) 1. İchmoq. 2. Chekmoq.

Ancak bu teknik hatalar sözlüğün değerini düşürmemektedir. Sonuç olarak Türkçe - Özbekçe Sözlük alanında temel kaynaklardan biri konumunda bulunarak ilgili bilimsel çalışmalara katkı sağlayacaktır. Eserin Özbekistan ve Türkiye ilişkilerinin hızla geliştiği bir dönemde yayımlanması ayrıca manidar olup, iki kardeş ülke ilişkilerinin gelişmesinde önemli bir katkı olacağına inanıyoruz. 